\title{
Contestability and sunk costs: an analysis of product R+D competition
}

Citation for published version (APA):

Bunte, F. H. J., \& Maks, J. A. H. (1997). Contestability and sunk costs: an analysis of product $R+D$ competition. METEOR, Maastricht University School of Business and Economics. METEOR Research Memorandum No. 015 https://doi.org/10.26481/umamet.1997015

Document status and date:

Published: 01/01/1997

DOI:

10.26481/umamet.1997015

Document Version:

Publisher's PDF, also known as Version of record

\section{Please check the document version of this publication:}

- A submitted manuscript is the version of the article upon submission and before peer-review. There can be important differences between the submitted version and the official published version of record.

People interested in the research are advised to contact the author for the final version of the publication, or visit the DOI to the publisher's website.

- The final author version and the galley proof are versions of the publication after peer review.

- The final published version features the final layout of the paper including the volume, issue and page numbers.

Link to publication

\footnotetext{
General rights rights.

- You may freely distribute the URL identifying the publication in the public portal. please follow below link for the End User Agreement:

www.umlib.nl/taverne-license

Take down policy

If you believe that this document breaches copyright please contact us at:

repository@maastrichtuniversity.nl

providing details and we will investigate your claim.
}

Copyright and moral rights for the publications made accessible in the public portal are retained by the authors and/or other copyright owners and it is a condition of accessing publications that users recognise and abide by the legal requirements associated with these

- Users may download and print one copy of any publication from the public portal for the purpose of private study or research.

- You may not further distribute the material or use it for any profit-making activity or commercial gain

If the publication is distributed under the terms of Article $25 \mathrm{fa}$ of the Dutch Copyright Act, indicated by the "Taverne" license above, 
Contestability and sunk costs: An analysis of product R\&D competition

Frank Bunte, Agricultural Economics Research Institute, The Hague, Netherlands ${ }^{*}$ Hans Maks, University Maastricht, Maastricht, Netherlands

Summary

The paper shows that Bertrand competition and contestability can be reconciled with sunk costs. When average total costs are constant over a range of output, marginal cost pricing does not conflict with the budget constraint faced by firms. Empirical observations support the notion of constant average total costs. When average total costs are constant, there is no trade-off between dynamic economies and static efficiency. The argument is applied to product R\&D competition.

JEL classification: L13, O31

Key-words: $\quad$ contestability, sunk costs, product R\&D

corresponding author: PO Box 29703, 2502 LS Den Haag, Netherlands, Phone: (31)

703308 326; Fax: (31) 703615 624; E-mail: f.h.j.bunte@lei.dlo.nl 


\section{Contestability and sunk costs}

\section{Introduction}

Mainstream theory on industrial organization suggests that it is almost impossible to reconcile contestability theory with sunk costs because of the Bertrand paradox. However, in this paper we will argue that contestability may be reconciled with sunk costs and that such a reconciliation is plausible from an empirical point of view. Consider the Bertrand paradox again. When there are two firms selling a homogeneous product with a constant returns to scale technology, Bertrand competition in combination with any level of sunk costs suffices to make the entry threat incredible and thus ineffective (Stiglitz, 1987; Dasgupta and Stiglitz, 1988). Because the entry threat is ineffective, the incumbent firm may reap monopoly profits. The argument can be illustrated briefly. When there are constant returns to scale, total costs $\mathrm{C}$ are as follows: $\mathrm{C}=\mathrm{S}+\mathrm{ac} . \mathrm{O}$ where $\mathrm{S}$ denotes sunk costs, $\mathrm{O}$ output and ac constant average variable costs. Homogeneity of goods and Bertrand competition suffice to enforce marginal cost pricing when there are two or more producers (with sufficient capacity). In this case, all firms in the industry suffer a loss equal to S. This argument explains why a second (or a third, etc.) firm never enters the industry and the monopolist is able to reap monopoly profits. Since it is necessary to incur sunk costs in order to perform research and development (R\&D), R\&D and Bertrand competition do not seem to be reconcilable. Bertrand competition eliminates the ability of firms to appropriate part of the surplus created by innovations and thus reduces the incentive to innovate to zero (Katz, 1986).

Stiglitz' result depends on the assumption of constant returns to scale in production. However, empirical observations suggest that average total costs are constant over a range of 
output for many industries despite the presence of sunk costs (Scherer and Ross, 1990, pp. 106-7). ${ }^{1}$ These observations have been the starting point for the cost relation modelled below. ${ }^{2}$ In the model outlined below average total costs are constant despite the presence of sunk costs. The fall in average sunk costs is matched by the rise in average variable costs, at least over the relevant range of output. When these cost relations are taken as a starting point for an analysis, Bertrand competition and (optimal) investments in R\&D can be shown to be reconcil-

\footnotetext{
${ }^{1}$ Average total costs are especially likely to be constant in industries producing more or less homogeneous products, like chemicals, aluminium and cement (Johnston, 1960; Levin, 1977; Moore, 1959; Walters, 1963). The range over which they are constant may be considerable: Average total costs are roughly constant for sulfuric acid for a range from 100,00 tons per year to $1,000,000$ tons per year (Levin, 1977). This, of course, does not imply that there is excess capacity over this range (Johnston, 1960). The survey by Walters (1963) suggests that constant returns to scale may refer to production costs only. As a result, average total costs are more likely to be decreasing for heterogeneous products (Morrison, 1990), since sunk ( $\& \& D$ and advertising) outlays are higher for heterogeneous products.

${ }^{2}$ Note that an equivalent observation has been used in contestability theory to defend constant returns to scale (Baumol, 1982).
} 
able. This can be illustrated briefly. In the paper average total costs $C$ are a linear function of output: $\mathrm{C}=$ ac. $\mathrm{O}$ (over some range of output). Sunk costs equal S and variable costs V are V $=\mathrm{ac} . \mathrm{O}-\mathrm{S}$. Marginal costs consequently are ac as well. When Bertrand prices are set, prices equal both average and marginal costs. So, when average total costs are (about) constant, Bertrand competition and R\&D may be reconciled. This result will be shown to be robust, just like the contestable results obtained by Baumol et al. (1983), Schwartz (1986) and Van Wegberg and Van Witteloostuijn (1992).

The cost function also allows several firms to co-exist in equilibrium. In this respect the paper differs from the literature on patent races which are won by one and only one firm (Tirole 1989), p. 394). This result makes our model more attractive than patent models, since winner-take-all games are hardly observed in reality. The argument just outlined is applied to product $R \& D$ competition. The paper analyses a two stage game in which second stage (price) competition is Bertrand. In the first stage the firms decide on product R\&D: the firms are able to raise product quality by performing $R \& D$.

The paper thus provides a way to incorporate the entry threat as laid down in contestability theory (Baumol, Panzar and Willig, 1982) into a dynamic framework. The paper hereby gives an example of a barrier market scenario (Van Witteloostuijn and Maks, 1988). Barrier market theory comprises competitive pricing with dynamic economies. Barrier market equilibria are characterized by zero profits, even under monopoly and oligopoly, and also by optimal investments in $\mathrm{R} \& \mathrm{D}$, since the entry threat is the force 'behind the introduction of dynamic economies of market behaviour' (op. cit., p. 117). The paper indeed shows that marginal cost pricing is not detrimental to dynamic economies (or the other way around): in equilibrium, price equals marginal cost while investments in product $R \& D$ are optimum.

The paper is organized as follows. Section 2 presents a general outline of the model and 
gives the model specification. Section 3 analyses firm behaviour and gives the analytical results. Section 4 ends with a conclusion.

\section{The model}

This section outlines the competition game we developed in order to analyse quality and price competition under the threat of potential entry. Sub-section 2.1 gives the model structure, subsection 2.2. the demand and cost specifications as well as the relations between product $R \& D$ expenses, quality and costs.

\subsection{The structure of a competition game}

In this paper, two markets are modelled, in both of which one incumbent firm is located. We model more than one market in order to endow both firms (and thus each potential entrant) with a home market. The entrants thus do not hang in the wings (Cairns and Mahabir, 1988). In both markets there are $\mathrm{N}$ consumers with identical preferences. The firms are able to enter each other's markets at an entry cost $\varepsilon$ per product. There are several explanations for these entry costs: (1) transportation costs, (2) product adaptation costs or (3) differences in preferences. There are no differences in entry costs across markets or producers. Both firms are incumbent in their home market and potential entrant in the other market. The firms do not face a capacity or any other resource constraint. This characteristic is closely bound up with the cost function chosen. 
Competition is modelled by a two stage game. Firms decide on product R\&D and price in order to maximize profits. In the first period the enterprises simultaneously decide on product $R \& D$ in order to improve the quality of the product offered for sale in the second period. In this period the firms simultaneously decide on price. When the firms determined their prices, the representative consumers in both countries decide which product to buy. They choose the consumer surplus maximizing price-quality offer. If the offers are equivalent, the incumbent firm is preferred. The structure of the two period game is summarized in Table 1.

\subsection{Demand and cost specifications}

\subsubsection{The demand system ${ }^{3}$}

In sub-section 2.1 we already indicated that there are two firms. Each firm $\mathrm{j}$ offers one variety $\mathrm{j}$ of the good under consideration $[\mathrm{j} \in\{1,2\}]$. In principle, the firms may offer a different variety, id est a different price-quality offer. The representative consumers buy only one of the varieties, the one maximizing consumer surplus. Consumers derive utility from the amount $\mathrm{X}_{\mathrm{j}}$ consumed of the variety maximizing consumer surplus and the amount $\mathrm{Z}$ consumed of the numéraire. Utility $\mathrm{U}$ is modelled by the following quasi-linear quadratic utility function

\footnotetext{
${ }^{3}$ The model is a special version of the one employed by Dixit (1979): the case of perfect substitutes. A simple general equilibrium version of the demand system is given by Horstmann and Markusen (1992).
} 
$U\left(X_{j}, Z\right)=Q_{j} X_{j}-\beta X_{j}^{2}+Z$

where $X_{j}$ denotes the quantity consumed of the good offered by firm $j, Q_{j}(>0)$ gives the quality of the good consumed and $\beta(>0)$ is a parameter. Note that utility differs per firm, since the quality level $Q_{j}$ may differ per firm. Taking account of the budget constraint: $P_{j} X_{j}+$ $\mathrm{Z}=\mathrm{Y}$, the following Marshallian and compensated individual demand function can be derived ${ }^{4}$

$X_{i}=\left[Q_{i}-P_{i}\right] / 2 \beta \quad\left(X_{e}=0\right) \quad$ if $Q_{i}-P_{i} \geq Q_{e}-P_{e}>0$

$X_{e}=\left[Q_{e}-P_{e}\right] / 2 \beta \quad\left(X_{i}=0\right) \quad$ if $Q_{i}-P_{i}<Q_{e}-P_{e}$

Subscript i refers to the incumbent firm; subscript e to the potential entrant. When the pricequality offers are equivalent: $\mathrm{Q}_{\mathrm{i}}-\mathrm{P}_{\mathrm{i}}=\mathrm{Q}_{\mathrm{e}}-\mathrm{P}_{\mathrm{e}}$, the incumbent's variety is preferred. This small advantage the incumbent enjoys relative to the potential entrant is well-known from contestability analysis.

\footnotetext{
${ }^{4}$ The budget constraint is assumed not to be binding for the consumption of variety $\mathrm{j}$. This implies that the consumption of the numéraire commodity is positive.
} 


\subsubsection{The cost function}

Technological progress requires the sinking of R\&D expenses. Sunk costs do not change as a result of a change in output. Average sunk costs thus decrease with output. Empirical studies nevertheless suggest that output is produced 'at more or less constant total costs per unit' (Scherer and Ross, 1990, pp. 106-7; italics added) over the relevant range of output. In order for average total costs to be constant, the fall in average sunk costs must be roughly matched by a rise in average variable costs. These costs thus are not constant as Stiglitz (1987) assumes. This observation has been the starting point of the cost functions defined. In the model exposed right now, average total costs are assumed to be a linear function of output. The condition of constant average total costs also guarantees that marginal costs are constant and identical to average total costs (page 2). Total costs $\mathrm{C}$ may thus be defined as follows

$\mathrm{C}_{\mathrm{j}}=\mathrm{ac}_{\mathrm{j}} \cdot \mathrm{O}_{\mathrm{j}}$

where ac denotes average total cost, $\mathrm{O}$ output and $\mathrm{j}$ one of the two firms $[\mathrm{j} \in\{1,2\}]$. For the moment we assume that capacity is large enough to cover any demand. The constancy of average total and marginal costs enables us to define relations between these cost levels and $\mathrm{R} \& \mathrm{D}$ expenses. The next section will be devoted to the derivation of these relations. Before we do so, we pay attention to some of the features of the above cost function.

As already illustrated in the introduction, average total costs equal marginal costs. ${ }^{5}$ As a result, marginal cost pricing and average cost pricing do not bite. This also implies that

\footnotetext{
${ }^{5}$ Total costs $\mathrm{C}=$ ac. $\mathrm{O}$ may be subdivided in sunk costs $\mathrm{S}$ and variable costs $\mathrm{V}=\mathrm{ac} . \mathrm{O}-\mathrm{S}$. Marginal costs are $\mathrm{dV} / \mathrm{dO}=\mathrm{ac}$.
} 
dumping is not profitable. Dumping is only profitable when average total costs (price) exceed marginal costs. The variable cost function implied by equation (3): $\mathrm{V}=$ ac.O-S imposes a restriction on the relevant range of supply. When $\mathrm{O}$ is small $(\mathrm{O}<\mathrm{S} / \mathrm{ac})$, variable costs are negative. Since (variable) costs cannot be negative, this range should be excluded from the analysis. Amortization of sunk costs usually complicates the entry deterrence game, because a mark-up over marginal costs needs to be charged (Baumol et al., 1982). However, because average total costs equal marginal costs, one does not need a mark-up over marginal costs to cover sunk costs in this model. The amortization problem is ruled out.

\subsubsection{Sunk costs, quality and marginal costs}

At each moment in time there is a set of possibilities for quality improvement. The exploration of these possibilities requires resources. Some of the possibilities do not require much effort (resources), but others do. Enterprises are likely to deal with the possibilities which do not require many resources first and the ones which require many resources later. The quality improvement resulting from spending the first guilder on product $R \& D$ expenses consequently is higher than the quality improvement resulting from spending the second, the tenth or the hundredth guilder on product $R \& D$. This implies that there are decreasing returns to investment in product $\mathrm{R} \& \mathrm{D}$. We therefore modelled the following relation between product R\&D RD and quality improvement

$\mathrm{Q}_{\mathrm{j}, 2}-\mathrm{Q}_{\mathrm{j}, 1}=\mu \sqrt{ }\left(\mathrm{RD}_{\mathrm{j}, 1}\right)$

where subscript 1 refers to period 1 and subscript 2 to period 2 and $\mathrm{j} \in\{1,2\}$. The relation 
between product R\&D and the change of quality is depicted in Figure 1. Average total and marginal costs are likely to rise when quality is improved upon. Because returns to investment are decreasing, costs rise at an increasing rate as a result of quality improvements. For this reason the relation between quality improvements and costs is modelled as follows

$\mathrm{ac}_{\mathrm{j}, 2}=\mathrm{mc}_{\mathrm{j}, 2}=\mathrm{mc}_{\mathrm{j}, 1}+\eta\left(\mathrm{Q}_{\mathrm{j}, 2}-\mathrm{Q}_{\mathrm{j}, 1}\right)^{2}$

Equation (5a) endogenizes average total and marginal cost. The relation between product $R \& D$ expenses and costs can be found by substituting equation (4) into equation (5a)

$\mathrm{ac}_{\mathrm{j}, 2}=\mathrm{mc}_{\mathrm{j}, 2}=\mathrm{mc}_{\mathrm{j}, 1}+\theta R D_{\mathrm{j}, 1}$

where $\theta=\eta / \mu^{2}$. The relation between product $R \& D$ expenses and average total and marginal costs is depicted in Figure 1. The relations given by equations (4) and (5b) suffice to guarantee a unique solution to the decisions on investment in product $R \& D$, because the function given by (4) is strictly concave, while that given by (5b) is convex.

\subsection{Analytical results}

\subsubsection{Firm behaviour}

Prices are characterized by the Bertrand solution. The firms compete for the consumers' favour. An incumbent only faces positive demand in its home market if its price-quality offer is not less favourable than its rival's offer. As a result, an entrant only faces positive demand in 
its entry market if its offer is more favourable than the incumbent's offer. For this reason gross profits are maximized subject to conditions with respect to the consumer surplus offered. Firm i's $[i \in\{1,2\}]$ maximization problem is

$\max \pi_{\mathrm{i}}=\Sigma_{\mathrm{m}}{ }^{2} \mathrm{X}_{\mathrm{i}, 2}{ }^{\mathrm{m}}\left(\mathrm{P}_{\mathrm{i}, 2}{ }^{\mathrm{m}}-\mathrm{mc}_{\mathrm{i}, 2}-\delta_{\mathrm{i}}{ }^{\mathrm{m}} \varepsilon\right)$

s.t. $\quad \mathrm{CS}_{\mathrm{i}, 2}{ }^{\mathrm{i}} \geq \mathrm{CS}_{\mathrm{e}, 2}{ }^{\mathrm{i}}$ and

$\mathrm{CS}_{\mathrm{i}, 2}{ }^{\mathrm{e}}>\mathrm{CS}_{\mathrm{e}, 2}{ }^{\mathrm{e}}$

where subscript e refers to the rival firm $[e \in\{1,2\}$ and $e \neq i]$, subscript 2 to period 2 and superscript $\mathrm{m}$ to market $\mathrm{m}[\mathrm{m} \in\{1,2\}]$. The term $\delta^{\mathrm{m}} \varepsilon$ indicates entry costs (or preference for the national variety); so, $\delta^{\mathrm{m}}=0$ if $\mathrm{i}=\mathrm{m}$ and 1 otherwise.

The constraints on the optimization problem determine the price decisions. Both prices follow from mere substitution out of the constraints, provided price is not lower than marginal cost. The highest price firm i may charge thus depends on its rival's marginal costs (including transport costs). Firm i prices according to equation (6) with $\mathrm{P}_{\mathrm{e}}$ equal to marginal cost, unless the resulting price is lower than firm i's marginal cost. Thus,

$\mathrm{P}_{\mathrm{i}, 2}{ }^{\mathrm{i}}=\max \left[\mathrm{Q}_{\mathrm{i}, 2}-\mathrm{Q}_{\mathrm{e}, 2}+\mathrm{mc}_{\mathrm{e}, 2}+\varepsilon, \mathrm{mc}_{\mathrm{i}, 2}\right] ;$

$\mathrm{P}_{\mathrm{i}, 2}{ }^{\mathrm{e}}=\max \left[\mathrm{Q}_{\mathrm{i}, 2}-\mathrm{Q}_{\mathrm{e}, 2}+\mathrm{mc}_{\mathrm{e}, 2}-\omega, \mathrm{mc}_{\mathrm{i}, 2}+\varepsilon\right]$

where $\omega \downarrow 0$.

Every firm decides on investment in $\mathrm{R} \& \mathrm{D}$ in the first period of each two period game knowing that its price decisions in the second period of each game are described by equation (7). The profit maximization problem can be modelled as follows 
$\max \Pi_{\mathrm{i}}=\Sigma_{\mathrm{m}}{ }^{2} \mathrm{X}_{\mathrm{i}, 2}{ }^{\mathrm{m}}\left(\mathrm{P}_{\mathrm{i}, 2}{ }^{\mathrm{m}}-\mathrm{ac}_{\mathrm{i}, 2}-\delta_{\mathrm{i}}^{\mathrm{m}} \varepsilon\right)$

where subscript $i$ refers to firm $i[i \in\{1,2\}]$, subscript 2 to period 2 and superscript $m$ to market $\mathrm{m}[\mathrm{m} \in\{1,2\}]$. The term $\delta^{\mathrm{m}} \varepsilon$ indicates entry costs, so $\delta^{\mathrm{m}}=0$ if $\mathrm{i}=\mathrm{m}$ and 1 otherwise. Demand $X_{i}$ is given by equation (2), quality $Q_{i}$ by equation (4), price $P_{i}$ by equation (7) and average cost $\mathrm{ac}_{\mathrm{i}}$ by equation (5b). Substituting for $\mathrm{X}_{\mathrm{i}}, \mathrm{Q}_{\mathrm{i}}, \mathrm{P}_{\mathrm{i}}$ and $\mathrm{ac}_{\mathrm{i}}$ and differentiating with respect to $R D_{i}$ gives the following level of product $R \& D^{6}$

$\mathrm{RD}_{\mathrm{i}, 1}=(\mu / 2 \theta)^{2}$

Equation (9) defines $R \& D$ investment as a function of $\mu$ and $\theta$. Product $R \& D$ rises with $\mu$ and decreases with $\theta$. This is not surprising since $\mu$ relates product $R \& D$ expenses and product innovations (equation (4)) and $\theta$ relates product $R \& D$ to $R \& D$ costs (equation (5b)).

Equation (1) to (9) determine the enterprises' equilibrium outcomes. Consider the two period game given by Table 1 again. When all firms start with the same quality and cost levels in period $1\left(\mathrm{Q}_{1}\right.$ and $\left.\mathrm{mc}_{1}\right)$, they all invest according to equation (9). Since the returns to $\mathrm{R} \& \mathrm{D}$ investment are not stochastic, they all end up with the same quality and cost levels in period 2 $\left(\mathrm{Q}_{2}\right.$ and $\left.\mathrm{mc}_{2}\right)$. Each firm is able to deter entry at a price equal to $\left(\mathrm{mc}_{2}+\varepsilon\right)$ and earns net profits equal to $\varepsilon X$. When $\varepsilon \downarrow 0$, net profits approach zero: gross profits just cover R\&D expenses. So, when average total costs are constant over the relevant range of output, Bertrand pricing

\footnotetext{
${ }^{6}$ This level also maximizes consumer surplus when the firm applies marginal cost pricing, i.e. takes the surplus maximising price decision.
} 
and sunk costs may be reconciled. This result contradicts Stiglitz' (1987) result.

\section{Discussion}

According to established IO literature the Bertrand paradox explains why pervasive price competition reduces or even eliminates R\&D competition (Stiglitz, 1987; or alternatively Dasgupta and Stiglitz, 1988; Katz, 1986; Sutton, 1991). ${ }^{7}$ In this paper we saw that this result depends on the assumption of constant economies to scale in production. However, empirical observations seem to suggest that average total costs are constant (Scherer and Ross, 1990). On the basis of these observations a cost function exhibiting constant average total costs is modelled, despite the presence of sunk costs. This cost function reconciles Bertrand and R\&D competition and solves the Bertrand paradox. Small changes in the model's parameters $(\mu, \theta$ and $\varepsilon$ ) lead to small changes in the equilibrium outcomes. Even when average total costs decrease slightly, contestable results may be approached. Both firms deter entry and capture a small positive profit level for $\varepsilon \downarrow \varepsilon^{*}(>0)$, when average total costs decrease slightly. In these respects, the above result is rather robust. ${ }^{8}$ The result is likely to hold in industries in which average total costs are about constant, i.e. in industries producing more or less homogeneous goods in which R\&D and advertising cost are not substantial (see footnote 1). Baumol et al. (1983), Schwartz (1986) and Van Wegberg and Van Witteloostuijn (1992), for instance, also

\footnotetext{
${ }^{7}$ However, a monopolistic inventor may find greater incentive to perform R\&D under competition than under monopoly (Arrow, 1962).

${ }^{8} \mathrm{~A}$ theory is robust with respect to a particular assumption if a (minor) change in this assumption leads to a minor change in the results [Schwartz (1986)].
} 
obtain contestable results as limit values. Overall, these results suggest that contestability theory is more robust than is commonly suggested (Martin 1994). There is also some indirect empirical support for contestability: Maks (1997) suggests that price-cost-margins are close to zero for a major part of the firms in the Netherlands in the period from 1987 to 1994.

The cost function also allows several firms to co-exist in equilibrium. In this respect the paper differs from the literature on patent races which are won by one and only one firm (Tirole, 1989). This result makes our model more attractive than patent models, since winnertake-all games are hardly observed in practice. The paper thus provides a way to incorporate the entry threat as laid down in contestability theory in a dynamic framework. The paper hereby gives an example of a barrier market scenario (Maks, 1986; Van Witteloostuijn and Maks, 1988). Barrier market theory comprises competitive pricing with dynamic economies. Barrier market equilibria are characterized by zero profits, even under monopoly and oligopoly, and also by optimal investments in $\mathrm{R} \& \mathrm{D}$, since the entry threat is the force 'behind the introduction of dynamic economies of market behaviour' (op. cit., p. 117).

\section{References}

Arrow, K.J. (1962): "Economic welfare and the allocation of resources for invention." In: NBER, The rate and direction of inventive actitvity, Princeton, Princeton UP.

Baumol, W.J. (1982): "Contestable markets: an uprising in the theory of industry structure." American Economic Review 72: 1-15.

Baumol, W.J., J.C. Panzar and R.D. Willig (1982): Contestable markets and the theory of industry structure, San Diego, Harcourt Brace Jovanovich.

Baumol, W.J., J.C. Panzar and R.D. Willig (1983): "Contestable markets: an uprising in the 
theory of industry structure: a reply." American Economic Review 73: 491-496.

Cairns, R.D. and D. Mahabir (1988): "Contestability: a revisionist view." Economica 55: 269-276.

Dasgupta, P. and J. Stiglitz (1988): "Learning-by-doing, market structure and industrial and trade policies." Oxford Economic Papers 40: 246-268.

Dixit, A. (1979): "A model of duopoly suggesting a theory of entry barriers." Bell Journal of Economics 10: 20-31.

Horstmann, I.J. and J.R. Markusen (1992): "Endogenous market structures in international trade (natura facit saltum)." Journal of International Economics 32: 109-129.

Johnston, J. (1960): Statistical cost analysis, New York, McGraw-Hill.

Katz, M.L. (1986): "An analysis of cooperative research and development." RAND Journal of Economics 17, 527-543.

Levin, R.C. (1977): "Technical change and optimal scale: some evidence and implications." Southern Economic Journal: 208-221.

Maks, J.A.H. (1986): "On the compatibility of the welfare state and the market economy." Albeda, W., ed.: The future of the welfare state, Maastricht, Presses Interuniversitaires Européennes.

Maks, J.A.H. (1997): Antitrust policy and imperfect information, The Netherlands 19871994, Maastricht.

Martin, S. (1994): Advanced industrial economics, Oxford, Blackwell.

Moore, F.T. (1959): "Economies of scale: some statistical evidence." Quarterly Journal of Economics: 232-245.

Morrison, C.J. (1990): Market power, economic profitability and productivity growth measurement: an integrated structural approach, NBER working paper 3355. 
Scherer, F.M. and D. Ross (1990): Industry market structure and economic performance, Boston, Houghton Mifflin.

Schwartz, M. (1986): "The nature and scope of contestability theory." Oxford Economic Papers S38: 37-57.

Stiglitz, J.E. (1987). "Technological change, sunk costs, and competition." Brookings Papers on Economic Activity 3: 883-947.

Sutton, J. (1991): Sunk costs and market structure: price competition, advertising, and the evolution of concentration, Cambridge MA, MIT Press.

Tirole, J. (1989): The theory of industrial organization, Cambridge MA, MIT Press.

Walters, A.A. (1963). "Production and cost functions: an econometric survey." Econometrica 31: 1-66.

Wegberg, M. van and A. van Witteloostuijn (1992): "Credible entry threats into contestable markets: a symmetric multimarket model of contestability." Economica 59: 437-452.

Witteloostuijn, A. van and J.A.H. Maks (1988): "Workable competition and the barrier market." European Journal of Political Economy 4: 117-135. 


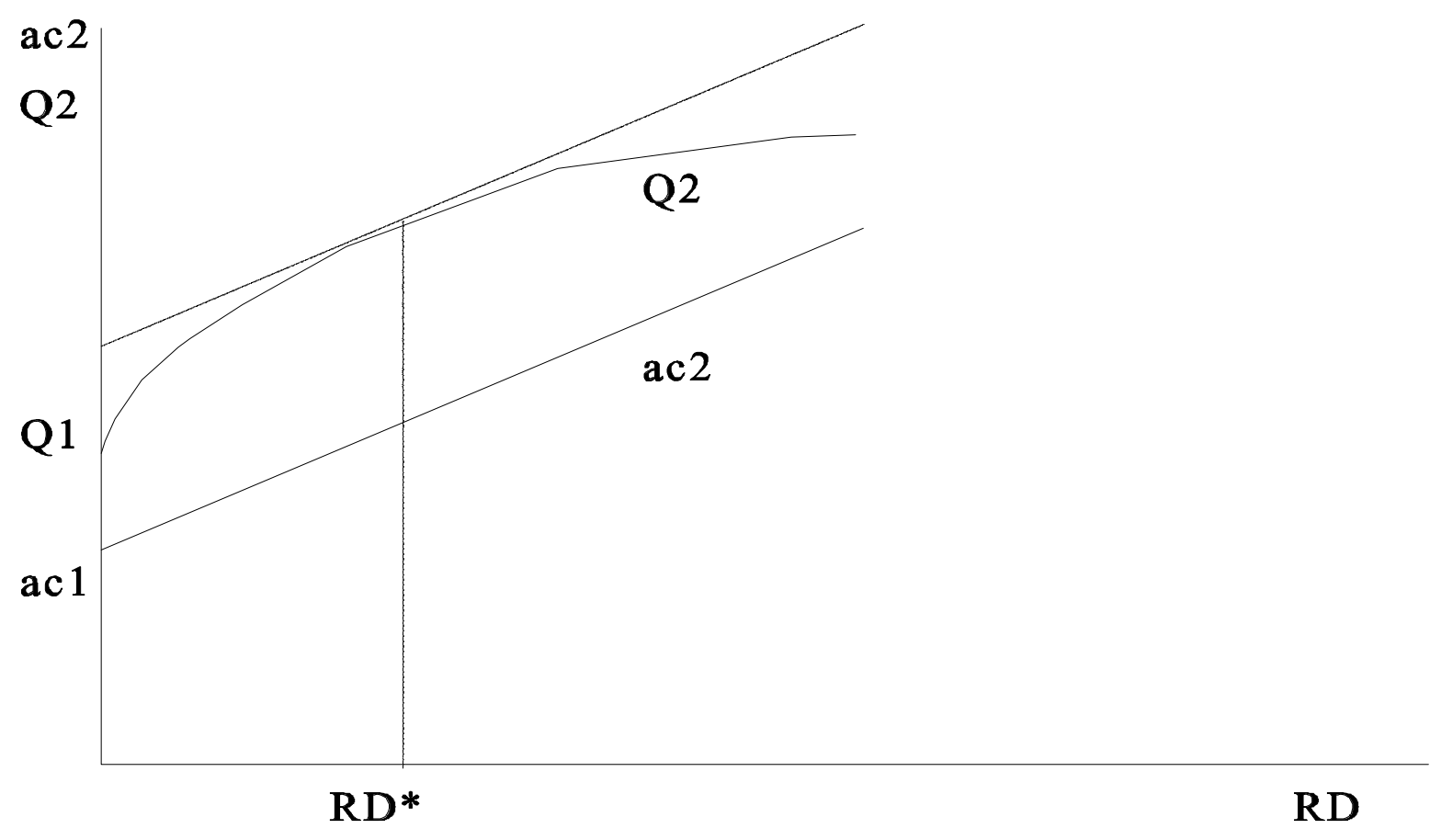

Figure 1: RD, quality and costs 


\begin{tabular}{|c|c|c|}
\hline \multicolumn{3}{|c|}{$\begin{array}{l}\text { Table } 1 \\
\text { Structure of the competition game }\end{array}$} \\
\hline Period & Stage & Enterprises' decisions \\
\hline 1 & 1 & Investment decisions \\
\hline \multirow[t]{2}{*}{2} & 1 & Price decisions \\
\hline & 2 & Market transactions \\
\hline
\end{tabular}

